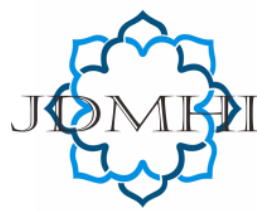

email: jdmhi@walisongo.ac.id

Journal of Digital Marketing and Halal Industry

ISSN: 2716-4810 (print) ISSN: 2716-4802 (online)

\title{
Competitive Advantages of Sharia Banks: Role of Ihsan Behavior and Digital Marketing in New Normal
}

\section{Mohamad Sodikin \\ Sekolah Tinggi Ilmu Ekonomi Cendekia Karya Utama, Semarang}

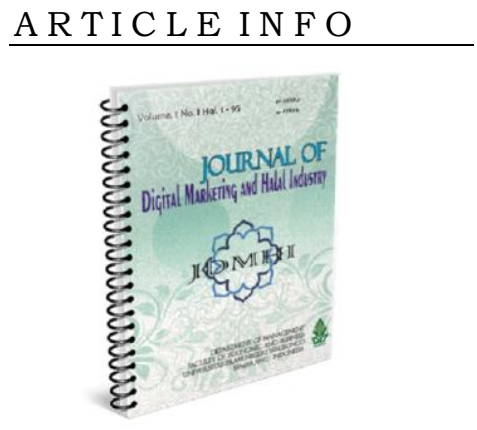

Article history:

Received 08 June 2020

Accepted 03 July 2020

Published 10 July 2020

Keywords:

Ihsan Behaviour, Digital

Communication Marketing,

Competitive Advantage, Brand

Image, New Normal
A B S T R A C T

Covid pandemic 19 had an impact on all aspects, one of which was related to Islamic banking. This article aims to discuss the role of Ihsan's behaviour as a foundation in building relationships with customers, building brand image through communication with the characteristics of Islamic values, and how organizations provide support so that the development of digital marketing communication runs effectively. The method uses a qualitative approach, with secondary data sources. Data analysis uses descriptive analysis approach. The results of the study show that the new pattern of life called the new normal as a result of the co19 pandemic has affected various sectors of social, economic, and even religious life. Islamic banks, as part of institutions that have an important role must be able to adapt and have a strategy to establish excellent communication and services with their customers. The business foundation, with the foundation of Ihsan values, with communication strategies through digital media, is expected to be able to increase the advantages of Islamic banks.

@2020 Journal of Digital Marketing and Halal Industry

\section{Introduction}

The banking sector is becoming increasingly competitive throughout the world. In particular, Islamic banks are a banking business that has core and actual products offered to business customers that can be considered relatively homogeneous, namely the Muslim community, although not close to other customers. Therefore there is a need for banks to increase their competitive advantage by differentiating themselves from competitors at the product level they have. One way that this can be achieved is by developing long-term relationships with their main customers (Heffernan, O'Neill, Travaglione, \& Droulers, 2008). Research (Pezeshki et al., 2011),

\footnotetext{
* Corresponding author. email: sodikinmohamad73@gmail.com DOI: http://dx.doi.org/10.21580/jdmhi.2020.2.1.5769
} 
confirms one of the important variables in relationship marketing in building long-term relationships and customer loyalty is through effective communication with customers. Which in this digital age, communication of this broadcast can be built through digital mode.

Digital marketing is defined as the practice of promoting products and services using digital distribution channels through mobile computing, smartphones, or other digital devices (Taken Smith, 2012). Empirical data reveals three important things that digital communication marketing (DMC) can provide positive benefits for communication in customer relations, sales support, and brand building (Karjaluoto, Mustonen, \& Ulkuniemi, 2015). The use of digital channels has changed the way marketers communicate with consumers today. Most consumers currently own and use a variety of digital media such as computers, mobile devices, and social media such as WhatsApp, Instagram, Facebook, YouTube, Twitter, which contribute to the extraordinary growth of digital advertising expenditure. Companies now recognize the need to listen to more of their customers, involve them in discussions, be transparent, and communicate with them openly and empathically. However, many organizations have not found a way to fully utilize this as an integral part of their overall marketing communication strategy (Karjaluoto et al., 2015), to contribute to the creation of an organization's competitive advantage.

This conceptual article aims to discuss the role of Ihsan behavior as a foundation in building relationships with customers, building brand image through communication with the characteristics of Islamic values, and how organizations provide support so that the development of digital marketing communication runs effectively. Finally, these variables can trigger organizational competitive advantage.

\section{Literature Review}

\section{Competitive Advantage}

There was once a time when people called it the era of comparative advantage, that is, the era of a country superior to other countries, because it has a wealth of nature, especially that, is not owned by other countries. Indonesia should be included in a country that has the abundant wealth to be able to surpass countries that are poor in natural resources. What is happening now is the opposite, that developed countries are those who are not richer in natural wealth but can realize their dreams through other countries. This is what is called the era of competitive advantage.

Having a competitive advantage means the country already has the advantage of either one country or several fields so that the country can win the competition. Marketing at this time has not yet connected the concepts of the micro-macro. Marketing needs to explore the macro aspects that cover: aspects of individual values and culture.

Factors of competitive strategies that affect competitive strategies, namely: Strengths and weaknesses of the company, opportunities, and industrial threats, community expectations, values shared by key executives. 12 Competitive advantage, according to Porter (1986), is the ability of a company to achieve economic benefits over the profits that can be 
achieved by competitors in the market in the same industry.

Companies that have competitive advantages always can understand changes in market structure and can choose effective marketing strategies. The choice of each company for the generic strategy above will depend on the analysis of the business environment to determine opportunities and threats.

Based on studies conducted by Porter, several ways to gain competitive advantage include offering products or services at a minimum price (cost leadership), offering products or services that are unique to competitors (differentiation), or focusing on specific segments (focus).

\section{Definition of Sharia Banking}

Banks are entities that raise funds from the public in the form of financing or in other words, carry out the financial intermediation function. In the banking system in Indonesia, there are two types of operational banking systems, namely conventional banks and Islamic banks. Under Law No. 21 of 2008 concerning Sharia Banking, Sharia Banks are banks that carry out business activities based on sharia principles or Islamic legal principles regulated in the fatwa of the Indonesian Ulema Council such as the principles of justice and balance ('adl wa tawazun), welfare (maslahah), universalism (naturally), and does not contain gharar, maysir, usury, wrongdoing and haram objects. In addition, the Sharia Banking Law also mandates Islamic banks to carry out social functions by performing functions such as the Baitul Mal institution, which receives funds from zakat, donations, alms, grants, or other social funds and channel them to waqf managers (nazir) as desired. Endowment (Waqf).

The implementation of the functions of sharia banking regulation and supervision from the aspect of the implementation of the principle of prudence and good governance is carried out by the OJK as is the case with conventional banking, but with the regulation and supervision system that is adjusted to the uniqueness of the sharia banking operational system. The problem of fulfilling Islamic principles is indeed unique to Islamic banks because essentially, Islamic banks are banks that offer products that are following Islamic principles. Compliance with Islamic policies is very fundamental because this is the basic reason for the existence of Islamic banks. Besides, adherence to Islamic principles is seen as the strength of Islamic banks. Consistent with the basic norms and principles of sharia, prosperity in the form of system stability, fairness in contracting, and the realization of good governance can be tangible.

\section{Digital Marketing}

Digital marketing has each definition. The understanding of Digital Marketing, according to experts, is as follows:

\section{Ridwan Sanjaya \& Josua Tarigan (2009)}

Digital marketing is a marketing activity, including branding, that uses various media. For example, blogs, websites, emails, Adwords, and various social media networks.

\section{Kleindl and Burrow (2005)}

Digital marketing is a process of planning and implementing concepts, ideas, prices, promotions, and distribution. It can simply be interpreted as the development and 
maintenance of a mutually beneficial relationship between consumers and producers.

\section{Heidrick \& Struggles (2009)}

Digital marketing uses the development of the digital world to do advertising that is not heralded directly but has a very substantial effect.

The number of digital marketing used by companies proves that Digital marketing has many advantages and benefits that can be obtained. Here are some of the advantages of digital marketing compared to conventional marketing.

\section{Spread Speed}

Marketing strategies using digital media can be done very quickly, even in seconds. Besides, digital marketing can also be measured in realtime and precisely.

2. Ease of Evaluation

By using online media, the results of marketing activities can be immediately known. Information such as how long your product was watched, how many people saw your product, what percentage of sales conversions from each ad, and so on. After knowing such information, then you can evaluate which ads are good and bad. So you can improve for the next period.

3. Broader Reach

The next advantage is the wide geographical range of digital marketing. You can spread your brand or product throughout the world with just a few easy steps by utilizing the internet.

4. Cheap and Effective
Compared to traditional marketing, of course, digital marketing is much cheaper and effective. Budget costs saved can be up to $40 \%$, according to Gartner's Digital Marketing Spend Report. Besides, the survey also shows that $28 \%$ of small entrepreneurs will move to digital because it is proven to be more productive.

5. Build a Brand Name

Digital marketing helps you build brand names well. The existence of cyberspace with the presence of your brand is essential because people will do an online search before buying your product.

\section{The Method, Data, and Analysis}

The method used in this study is a qualitative descriptive method. Qualitative descriptive refers to the identification of the characteristics that distinguish or characteristics of a group of people, things, and events. Qualitative descriptive involves the conceptualization process and results in the formation of classification schemes. In addition to describing the characteristics of a symptom or problem under study, this study also focuses on the basic 'how' questions by trying to obtain and convey facts clearly, thoroughly, and completely without any unnecessary details (Silalahi, 2010).

\section{Result and Discussion}

\section{Role of Ihsan Behavior in business}

The view of life adopted by a person or group influences how he sees himself, his life goals, and his environment (Mas'ud, 2017). According to Quraish Shihab, the values and 
beliefs that drive behaviour and control the human soul in the Qur'an are called ilah (Shihab, 1999). The conventional business concept is the business concept of the United States, which is then followed by Europeans, Asians, and others (Handy, 2008). The central values are freedom, competition, individualism, the orientation of money, and profit (De George, 1982).

This is different from the values that are based on the Islamic way of life. The Islamic way of life can be interpreted as a Muslim understanding of the basic beliefs about his God that is Allah SWT, revelation (Al Quran), Rasulullah SAW, the universe, the purpose of creation, the reality of reality, the essence of creation, the purpose of human life, knowledge, truth, truth and happiness (Mas'ud, 2017). In this case, the Koran and the Hadith become the basic foundation of Muslims in behaving, interacting or muamalah. This means that economic or business activities are not value-free, not only individual, material, worldly oriented but also social, spiritual, and ukhrowi. Achieving one goal must not be done by weakening or even harming and destroying the other party, even if someone has the power to do it. Everything has to do with Ihsan values. Allah Almighty says in the Qur'an: Verily Allah tells (you) to be just and do good, give to relatives, and Allah forbids cruel Munkar and hostility. He teaches you so that you can take lessons ". (Abdul Azis Abdul Rauf, Lc and Andi Subarkah, 2018).

The verse contains a lesson that we are ordered to do justice and virtue (ihsan), and are prohibited from doing heinous deeds, munkar which can cause damage. Two values are significant to encourage very high performance, which is always mentioned in the Qur'an and Hadith, namely mas'uliyyah (responsibility) and ihsan (virtue) (Mohiuddin, MG, GO Yusof, 2013; Furqani, 2015; Irmadariyani, Fadah, Tobing, \& Wardayati, 2016)

Related to ihsan, in the context of building a competitive advantage, there is the story of Abdurrahman bin Auf's friends as follows, the story began when Abdurrahman bin Auf joined the emigration to Medina. All the wealth that had been collected suddenly 'sold out' after being taken away by the Quraysh ruler. He came to Medina with no wealth at all. While in Medina, Abdurrahman started a business from scratch. He is famous for his business of cheese and samin oil. It did not take long, and trading profits were increasing. Abdurrahman ibn Awf was a genius and clever trader. When he went to the market, he not only traded, but he also watched closely. From his observations, he knew, Jewish merchants apparently owned the stalls occupied by traders. The traders selling there rented the land, not much different from the traders who rent stalls at the mall now. Abdurrahman had a creative idea, as well as an effort to break the hegemony of Jewish merchants. He asked for help from his new brother to buy a less valuable land located next to the market. The land is then mapped. There are great facilities. Anyone can take water and sell on the land without paying rent. If they benefit from trading there, he urges them to share the results sincerely. Of course, the traders were happy because the usual operational costs incurred reduced a lot. Long story short, the traders also flocked to move to the market developed by Abdurrahman bin Auf (Zunus, 2019).

The story inspired how to build excellence by creating relationship values based on the nature of ihsaniyah to customers and trading 
partners. This is relevant to (Gilboa, SegerGuttmann, \& Mimran, 2019), that strategies in building communication and personal qualities increase trust in business, and building positive social relationships will foster commitment. The story also shows that Abdurrahman bib Auf has a strong absorptive capability. This absorption can become an intangible instrument to enter new knowledge that supports innovation and performance (Kostopoulos, Papalexandris, Papachroni, \& Ioannou, 2011; Tzokas, Kim, Akbar, \& AlDajani, 2015). Both of these capacities can be a strategy to build service quality, customer satisfaction, and loyalty, which triggers positive customer relationships. This is an important element for maintaining a competitive advantage (Zeithaml, Berry, \& Parasuraman, 1996).

The pattern of life in the new normal era that is echoed by various parties needs to be translated into life back to the order of life, which is based on the nature of ihsan in all respects as guided in the Qur'an. Including how we build communication in this new normal era must also use methods and content that is following the values of ihsaniyah.

\section{The Role of Communication in building Islamic bank brand performance.}

The brand is a name, term, sign, picture, or a combination of these, which serves to identify the company's goods or services and distinguish them from competing goods (Chinomona, 2016). The brand is an asset and a source of competitive advantage for producers and retailers. Through the brand, the company can communicate to customers the value of a product and their experience to consumers. Brand communication is when an idea or image of a product or service is marketed so that the distinctiveness is identified and recognized by many consumers (Chinomona, 2016). The literature shows that brand communication is consistently seen as playing an important role in creating a positive brand attitude (Keller \& Lehmann, 2006). Therefore to develop key integrative elements in managing brand relationships with customers and creating positive brand attitudes such as brand satisfaction and brand trust (Runyan \& Droge, 2008), effective communication skills need to be built.

The communication developed is positive, open, and fair communication ethics. Ethics, according to (Shadab, 2012) is interpreted as a reciprocal relationship based on fair exchange, where customers feel a beneficial, open relationship. A seller with good ethics will build a good relationship with the customer. If the seller provides correct information, the customer will be more satisfied with the service, thereby increasing trust and satisfaction, and will be followed by recommendations to other parties. The seller shows one of the ethical selling behaviors by not only interested in his interests but also in the interests of customers, the seller does not exaggerate the features and benefits of his policy, and the seller does not lie when competing in sales (Asyhari, Pudjihastuti, \& Kurdaningsih, 2018). There is one example of a conventional form of communication in the retail business that is in communicating prices. They write a $50 \%+20 \%$ discount. This communication can be assessed as communication that is not open. This is because at first glance, buyers will see it as a $70 \%$ discount when in fact, the writing is the same as a $60 \%$ discount, but why not write it 
with $60 \%$. It seems that there is an element of "psychological manipulation" to consumers. Conventional business concepts like this are actually US business concepts that are then followed by Europeans, Asians, and others (Handy, 2008). The central values are freedom, competition, individualism, the orientation of money, and profit (De George, 1982). This is different from the values that are based on the Islamic way of life. The Islamic way of life can be interpreted as a Muslim understanding of the basic beliefs about his God that is Allah SWT, revelation (Al Quran), Rasulullah SAW, the universe, the purpose of creation, the reality of reality, the essence of creation, the purpose of human life, knowledge, truth, truth, and happiness (Mas'ud, 2017). This means that economic or business activities are not value-free, not only individual, material, worldly oriented but also social, spiritual, and ukhrowi.

So the consistent, competent, honest, open, fair, responsible, and kind behavior of the seller will influence the customer's perception of the company. This is relevant to (Gilboa et al., 2019), which states that strategies in building communication and personal qualities will increase trust in business, and build social relations I. Closing The new life patterns referred to as new normal as a result of the co-19 pandemic have affected various sectors of social, economic, and even religious life. Islamic banks, as part of institutions that have an important role in the economic activities of the people must be able to adapt and have a superior strategy to be able to continue to establish communication with its customers and even expand their service capabilities to the community. The business foundation with the Islamic worldview foundation is the value of ihsan and communication strategy through digital media with the characteristics of Islamic communication is expected to be able to improve the advantages of Islamic banks so that they can provide services to the public widely and sustainably. Positive will grow commitment. In line with this (Luxton, Reid, \& Mavondo, 2015), confirm that marketing communication capacity has a positive relationship with good brand performance.

There are several benefits associated with developing a marketing communication capability. This capability will help companies focus on optimizing the utilization of their resources (time, effort, and financial) towards customers, starting from determining what to say and then finding prospects to whom to say it and how to say it needs to be designed to bring all elements of marketing communication to be credible, persuasive, become meaningful and measurable processes that can be evaluated for effectiveness and efficiency (Ratnatunga \& Ewing, 2009; Luxton et al., 2015). In order for this communication to contribute to competition and excellence in brands, communication needs to be built that have characteristics that are valuable, rare, cannot be imitated, cannot be replaced (Barney, 1991). In the concept of Islam, there are several characteristics of communication that can be developed to build excellence and trust, namely qaulan sadiidan: namely true communication, both in terms of substance and redaction (QS. Al Ahzab: 70; An Nisa: 9), qaulan baligha: namely effective, communicative, easy to understand (QS.Anisa: 63), qaulan maysura: proper, pleasant, easy communication (QS, Al Isra: 28), qaulan layyina: smooth, gentle, friendly communication, leaving a positive impression (QS.Thoha: 44), qaulan ma'rufa: good message, not frightening (QS.An Nisa: 5,8; Al Baqarah: 235,263; Al Ahzab: 32), qaulan karima: 
smooth, gentle, full of respect (QS.Al Isra; 23). Some of these characteristics can be guidelines for how we build Islamic communication, including the substance, ways, and to whom communication is developed. Communication must contain the correct information, be delivered in a way, and language that is good, easy to understand, contains a persuasive value, fair, honest, and does not interfere with other parties. This capacity must be developed continuously because of the theory of resourcebased view (RBV) that the company's ability to communicate and brand assets as company resources can be a positive market-based potential or return on other assets (Ratnatunga \& Ewing, 2005). These capabilities can be developed to increase brand image in Islamic banks.

An Islamic bank is a financial institution that is run following Islamic principles, which in practice distinguishes it from conventional banks. There is strategic importance that is owned by Islamic banks as a competitive advantage that is communicated with customers, namely halal value. This asset can be used by Islamic banks to image building and trust of customers, especially in the Muslim community, which is a potential market for Islamic banks. Customer trust in banks is a valuable asset for banks. This is because trust is considered the basic foundation of the relationship between the bank and the customer. Banks with a good reputation will generally be more attractive to prospective customers, because they believe the bank is of good quality and can be trusted. Trusted banks are guarantees for consistent product performance and are provided for each customer's needs (Hidayat, Rachmad, and Akhmad, 2015). The decision to repeat the transaction is actually influenced by the customer's attitude to the product or service from the seller (Taylor, S. A., \& Hunter, 2003). Attitude is a comprehensive evaluation that allows a person to respond in a way that is beneficial or not to the object being evaluated (Louro, Pieters, \& Zeelenberg, 2005). Transaction behavior is one of many things that can be influenced by service quality (Preis, 2003). The results of research conducted (Hidayat, Rachmad and Akhmad, 2015), show that religious commitment has a significant relationship to loyalty and the decision to transact in sharia banking services. However, research (Aspan, Sipayung, Muharrami, \& Ritonga, 2017), related to the effects of halal labels, brand image, and decisions on the use/purchase of services is still relatively small. This certainly requires stronger socialization and communication to the public regarding products and advantages of Islamic banks.

Digital support of the organization in building sharia bank excellence

There are two approaches in strategic management (Varadarajan, 1999) in building excellence, namely through content and process approaches. In terms of content, Islamic banking can develop the potential and capabilities of banks, namely human resources, so that they have good communication capacity, adaptability capacity and have an effect on high organizational performance (Wei \& Lau, 2010). This capability is needed to meet the changing demands and dynamic needs of customers. In the process approach, Islamic banking can use digital marketing as a marketing medium to communicate and provide quality service to customers.

Work patterns and communication through 
digital media involve physical abilities, login if changes, work demands and high work involvement (Sardeshmukh, Sharma, \& Golden, 2012), such conditions can have an impact on employee fatigue, if organizational support is low (Bosua et al., 2012; Sardeshmukh et al., 2012; Coenen \& Kok, 2014). Therefore the organization must provide extensive support to employees. A positive work environment and organizational support can foster employees' personal resources that increase their psychological strength (Michel, Kavanagh, \& Tracey, 2013). In line with this, employees who perceive emotional and instrumental support from their organizations or coworkers have a positive effect on employee welfare (Rego, Sousa, Marques, \& Pina e Cunha, 2014). Empirical evidence (Karatepe, 2015) states that personal resources fully mediate the role of organizational support and the desire of employees to leave their jobs. This condition also makes the employee will be able to overcome his emotional fatigue. This means that employees who get positive contributions and support for their work can increase their motivation and efficacy. Based on these studies, organizations must be able to provide support to their employees to support the effectiveness of their communication.

The forms of organizational support that can be carried out (Bentley et al., 2016) are as follows: (1). Organizations can provide useful advice and information technology to employees in carrying out work through digital methods. (2). Giving confidence to employees that they will be able to carry out and complete their tasks with the telework method. (3). Providing work support facilities and instrumental organizational support. For example: providing credit assistance or data packages or other relevant instruments to support the work. (4). Provide solutions if problems occur when employees work through telework. (5). Training with a team base and multi-skills for the development of human resources supporting the implementation of online marketing. In addition to instrumental support, the role and social support of organizational leaders and colleagues are also important in the post-19 pandemic period. Psychological strength possessed by the leader, the leader's strategy in overcoming emotional distress can be "transmitted" to his employees so that individually and in groups, employees can overcome the conditions and conditions experienced together. Emotional transmission (Barsade, 2002) is a process in which a person or group influences the emotions or behavior of other people or groups through the induction of emotional states and behaviors consciously or unconsciously.

This is important because social support makes employees feel they are not alone in overcoming and facing difficult times due to this co-19 pandemic or adapting to new life patterns (new normal). In line with this, the study of Rhoades and Eisenberger (2002) confirms that expansive positive and friendly behavior will cause employees to make a good impression on others and will trigger more effective work relationships with coworkers and superiors. Employees who perceive that some policies and procedures allow them to make decisions, see and receive emotional support from their superiors and coworkers will have high effectiveness. The social cognitive theory supports this that when individuals get realistic impulses, they tend to exert more effort and potential to fulfill the quality of work and be more successful than individuals who have problems with self-doubt (Wood, R. and Bandura, 1989). However, of course, not all organizations have provided 
such support, which is due to limitations and differences in the potential resources of the organization to support the work of its employees. This obstacle can be overcome by collaborating with other large banks. Through this strategic approach, it is hoped that sharia banking will be able to compete and provide broad benefits to the public.

\section{Conclusion}

The new life patterns referred to as new normal as a result of the co-19 pandemic have affected various sectors of social, economic, and even religious life. Islamic banks as part of institutions that have an important role in the economic activities of the people, must be able to adapt and have a superior strategy to be able to continue to establish communication with its customers and even expand their service capabilities to the community. The business foundation with the Islamic worldview foundation is the value of ihsan and communication strategy through digital media with the characteristics of Islamic communication is expected to be able to improve the advantages of Islamic banks so that they can provide services to the public widely and sustainably.

\section{Recommendation}

Islamic banks as part of Islamic institutions have an important role in the economic activities of the people must be able to adapt and have a superior strategy to be able to continue to establish communication with their customers and even expand their service capabilities to the public, especially in the new normal era as it is today. Improvements in the provision of technology such as mobile banking or internet banking are also very necessary to be able to improve services to the public so as to provide a positive image of Islamic banks throughout Indonesia.

\section{References}

Abdul Azis Abdul Rauf, Lc dan Andi Subarkah, L. (2018). Al Qur'anul Karim Al- Hufaz. Bandung: Cordoba.

Aspan, H., Sipayung, I. M., Muharrami, A. P., $\&$ Ritonga, H. M. (2017). The Effect of Halal Label, Halal Awarness, Product Price, and Brand Image to the Purchasing Decision on Cosmetic Products (Case Study on Consumers of Sari Ayu Martha Tilaar in Binjai City). International Journal of Global Sustainability, $\quad 1(1), \quad 55$. https://doi.org/10.5296/ijgs.v1i1.12017

Asyhari, A., Pudjihastuti, S. H., \& Kurdaningsih, D. M. (2018). Peran mediasi keunggulan kompetitif pada faktor determinan kinerja bisnis UKM di sentra tenun batik di Jawa Tengah. Jurnal Siasat Bisnis, 22(2), 111-131. https://doi.org/10.20885/jsb.vol22.iss2. art1

Barney, J. (1991). Firm Reources ad Sustained Competitive Advantege. Journal of Management, Vol. 17, pp. 99-120.

Barsade, S. G. (2002). The ripple effect: Emotional contagion and its influence on group behavior. Administrative Science Quarterly, 47(4). https://doi.org/10.2307/3094912

Bentley, T. A., Teo, S. T. T., McLeod, L., Tan, 
F., Bosua, R., \& Gloet, M. (2016). The role of organizational support in teleworker wellbeing: A socio-technical systems approach. Applied Ergonomics, 52 , 207-215. https://doi.org/10.1016/j.apergo.2015.0 7.019

Bosua, R., Nederland, O. U., Gloet, M., Kurnia, S., \& Mendoza, A. (2012). Telework, productivity and. (October).

Chinomona, R. (2016). African Journal of Economic and Management Studies Article information: African Journal of Economic and Management Studies, VII(1). https://doi.org/10.1108/AJEMS-062016-0088

Coenen, M., \& Kok, R. A. W. (2014). Workplace flexibility and new product development performance: The role of telework and flexible work schedules. European Management Journal, 32(4), 564-576.

https://doi.org/10.1016/j.emj.2013.12. 003

De George, R. T. (1982). What is the American business value system? Journal of Business Ethics, 1(4), 267-275. https://doi.org/10.1007/BF00382813

Furqani, H. (2015). Individual and society in an Islamic ethical framework Exploring key terminologies and the microfoundations of Islamic economics. Humanomics, 31(1), 74-87.

Gilboa, S., Seger-Guttmann, T., \& Mimran, O. (2019). The unique role of relationship marketing in small businesses' customer experience. Journal of Retailing and Consumer Services, 51(May), https://doi.org/10.1016/j.jretconser.201 9.06.004

Handy, C. (2008). What is Business For? 1-9.

Heffernan, T., O’Neill, G., Travaglione, T., \& Droulers, M. (2008). Relationship marketing: The impact of emotional intelligence and trust on bank performance. International Journal of Bank Marketing, 26(3), 183-199. https://doi.org/10.1108/026523208108 64652

Hidayat, Rachmad and Akhmad, sabarudin. (2015). The Influence of Service Quality, Religious Commitment and Trust On The Customers' Satisfaction and Loyalty And Decision To Do The Transaction In Mandiri Sharia Bank Of Jawa Timur. AlUlum, 15(57-90).

Irmadariyani, R., Fadah, I., Tobing, D. S. K., \& Wardayati, S. M. (2016). Accounting and Finance Review Initiating the Concept of Ihsan into Shari ' ah ' $s$ Corporate Social Responsibility. 1(1), 19-26.

Karatepe, O. M. (2015). Do personal resources mediate the effect of perceived organizational support on emotional exhaustion and job outcomes? International Journal of Contemporary Hospitality Management, 27(1), 4-26. https://doi.org/10.1108/IJCHM-092013-0417

Karjaluoto, H., Mustonen, N., \& Ulkuniemi, P. (2015). The role of digital channels in industrial marketing communications. Journal of Business and Industrial Marketing, 30(6), 703-710. https://doi.org/10.1108/JBIM-04-20130092 
Keller, K. L., \& Lehmann, D. R. (2006). Brands and branding: Research findings and future priorities. Marketing Science, 25(6), 740-759. https://doi.org/10.1287/mksc.1050.015 3

Kostopoulos, K., Papalexandris, A., Papachroni, M., \& Ioannou, G. (2011). Absorptive capacity, innovation, and financial performance. Journal of Business Research, 64(12), 1335-1343. https://doi.org/10.1016/j.jbusres.2010. 12.005

Louro, M. J., Pieters, R., \& Zeelenberg, M. (2005). Negative Returns on Positive Emotions: The Influence of Pride and Self-Regulatory Goals on Repurchase Decisions. Journal of Consumer Research, 31(4), 833-840. https://doi.org/10.1086/426619

Luxton, S., Reid, M., \& Mavondo, F. (2015). Integrated marketing communication capability and brand performance. Journal of Advertising, 44(1), 37-46. https://doi.org/10.1080/00913367.201 4.934938

Mas'ud, F. (2017). Manajemen Bisnis Berbasis Pandangan Hidup Islam. Semarang: UNDIP Press.

Michel, J. W., Kavanagh, M. J., \& Tracey, J. B. (2013). Got Support? The Impact of Supportive Work Practices on the Perceptions, Motivation, and Behavior of Customer-Contact Employees. Cornell Hospitality Quarterly, 54(2), 161-173. https://doi.org/10.1177/193896551245 4595

Mohiuddin, M.G., G.O. Yusof, and A. B. (2013). "Organizing: An Islāmic
Perspective." Global Disclosure of Economics and Business 2, No. 2, 6072.

Pezeshki, V., Mousavi, A., Rakowski, R. T., Pauwels, K. H., Silva-Risso, J., Srinivasan, S., ... Ekonomi, F. (2011). The Role of Relationship Marketing in Customer Orientation Process in the Banking Industry with focus on Loyalty. Ssrn, 3(1), 155-167. https://doi.org/10.32400/ja.4947.3.1.2 014.122-133

Preis, M. W. (2003). The Impact of Interpersonal Satisfaction on Repurchase Decisions. Journal of Supply Chain Management, 39(2), 30-38. https://doi.org/10.1111/j.1745493X.2003.tb00157.x

Ratnatunga, J., \& Ewing, M. T. (2005). The brand capability value of integrated marketing communication (imc). Journal of Advertising, 34(4), 25-40. https://doi.org/10.1080/00913367.200 5.10639214

Ratnatunga, J., \& Ewing, M. T. (2009). An exante approach to brand capability valuation. Journal of Business Research, 62(3), 323-331. https://doi.org/10.1016/j.jbusres.2008. 04.003

Rego, A., Sousa, F., Marques, C., \& Pina e Cunha, M. (2014). Hope and positive affect mediating the authentic leadership and creativity relationship. Journal of Business Research, 67(2), 200-210. https://doi.org/10.1016/j.jbusres.2012. 10.003

Runyan, R. C., \& Droge, C. (2008). A categorization of small retailer research 
streams: What does it portend for future research? Journal of Retailing, 84(1), 77 94.

https://doi.org/10.1016/j.jretai.2008.01 .003

Sardeshmukh, S. R., Sharma, D., \& Golden, T. D. (2012). Impact of telework on exhaustion and job engagement: $\mathrm{A}$ job demands and job resources model. New Technology, Work and Employment, 27(3), 193-207. https://doi.org/10.1111/j.1468005X.2012.00284.x

Shadab, R. (2012). Effects of Ethical Sales Behavior Considered Through Transaction Cost Theory: To Whom is the Customer Loyal? Oman Chapter of Arabian Journal of Business and Management Review, 2(5), 30-37. https://doi.org/10.12816/0002265

Shihab, M. Q. (1999). Membumikan Al Quran: Fungsi dan Peran wahyu dalam Kehidupan Masyarakat. Bandung: Mizan.

Taken Smith, K. (2012). Longitudinal study of digital marketing strategies targeting Millennials. Journal of Consumer Marketing, $\quad$ 29(2), 86-92. https://doi.org/10.1108/073637612112 06339

Taylor,S. A., \& Hunter, G. (2003). An exploratory investigation into the antecedents of satisfaction, brand attitude, and loyalty within the (B2B) eCRM industry. Journal of Consumer Satisfaction Dissatisfaction and Complaining Behavior, 16.

Tzokas, N., Kim, Y. A., Akbar, H., \& AlDajani, H. (2015). Absorptive capacity and performance: The role of customer relationship and technological capabilities in high-tech SMEs. Industrial Marketing Management, 47, 134-142. https://doi.org/10.1016/j.indmarman.2 015.02 .033

Varadarajan, P. R. (1999). Strategy Content and Process Perspectives Revisited. Journal of the Academy of Marketing Science, 27(1), 88-100. https://doi.org/10.1177/009207039927 1007

Wei, L. Q., \& Lau, C. M. (2010). High performance work systems and performance: The role of adaptive capability. Human Relations, 63(10), 1487-1511.

https://doi.org/10.1177/001872670935 9720

Wood, R. and Bandura, A. (1989). Social cognitive theory of organizational management. Academy of Management Review, 14(No.3), 361-384.

Zeithaml, V. A., Berry, L. L., \& Parasuraman, A. (1996). The Behavioral Consequences of Service Quality. Journal of Marketing, 60(2), 31-46. https://doi.org/10.1177/002224299606 000203

Zunus, M. Pelajaran Bisnis dari Sahabat Abdurrahman bin Auf. , (2019). 
Journal of Digital Marketing And Halal Industry

Vol. 2, No. I (2020) 1-14 